\title{
Orofacial clefts: treatment based on a multidisciplinary approach
}

Fissuras labiopalatinas: tratamento baseado em uma abordagem multidisciplinar

Fisuras labio-palatinas: tratamiento basado en un enfoque multidisciplinario

Jefferson David Melo de MATOS $^{1}$

Leonardo Jiro Nomura NAKANO ${ }^{1}$

André Guimarães RODRIGUES ${ }^{2}$

Alessandra Dossi PINTO ${ }^{3}$

Mateus Favero Barra GRANDE ${ }^{4}$

Marco Antonio BOTTINO 5

Guilherme da Rocha Scalzer LOPES ${ }^{1}$ Valdir Cabral ANDRADE ${ }^{5}$

${ }^{I}$ Post Graduate Student - Ph.D Program, Department of Dental Materials and Prosthodontics, São Paulo State University (Unesp), Institute of Science and Technology, São José dos Campos - SP, Brazil

${ }^{2}$ Doctor of Dental Surgery - Universidade Vila Velha (UVV), Vila Velha - ES, Brazil

${ }^{3}$ Graduated in Dentistry - Faculdade São Francisco de Assis (ESFA), Santa Teresa - ES, Brazil

${ }^{4}$ Post Graduate Student - Masters Degree Program, Department of Dental Materials and Prosthodontics, São Paulo State University (Unesp), Institute of Science and Technology, São José dos Campos - SP, Brazil

${ }^{5}$ Full Professor of Postgraduate Program in Restorative Dentistry, Department of Dental Materials and Prosthodontics, São Paulo State University (Unesp), Institute of Science and Technology, São José dos Campos - SP, Brazil

${ }^{6}$ Professor Adjunct - Department of Dentistry, Universidade Federal de Juiz de Fora (UFJF), Governador Valadares - MG, Brazil

\section{Abstract}

Objective: The present study aims to expose through a literature review the cleft lip and/or cleft palate (CL/CP) and its treatment in a multidisciplinary approach. Methodology: This literature review was conducted by the leading health databases: Pubmed (https://www.ncbi.nlm.nih.gov/pubmed). The keywords for the textual search were: Cleft Lip; Cleft Palate; Dental Staff; Classification; Embryology. The inclusion criteria were: literature on the subject under study, literature of the last years, english language, laboratory and clinical studies and systematic review. Literature Review: Fissures can be defined by a space at the junction between two bones, usually where there would be a suture. Orofacial clefts are part of the congenital facial anomalies resulted from the non-junction of the embryonic facial processes. These changes occur due to an alteration in the migratory velocity of the neural crest cells, in charge of the phenomenon of fusion of the facial prominences between the $6^{\text {th }}$ and $9^{\text {th }}$ week of embryonic life. Conclusion: The treatment of patients with orofacial clefts requires the approach of a multidisciplinary team that involves physicians in the area of plastic surgery, otorhinolaryngology, pediatrics, geneticists, dentists, prosthetics, nurses and speech pathologists, focusing on patient prevention, recovery and rehabilitation. However, further studies are needed for a better understanding of the subject and the steps that should be applied for each particular case.

Descriptors: Cleft Lip; Cleft Palate; Dental Staff; Classification; Embryology.

\section{Resumo}

Objetivo: O presente estudo tem por objetivo, expor através de uma revisão da literatura as fissuras labiais e/ou palatinas (FL/P) e seu tratamento, diante de uma abordagem multidisciplinar. Metodologia: Esta revisão de literatura foi conduzida pelo principal banco de dados de saúde: Pubmed (https://www.ncbi.nlm.nih.gov/pubmed). As palavras-chave para a busca textual foram: Fenda Labial (Cleft Lip); Fissura Palatina (Cleft Palate); Equipe Hospitalar de Odontologia (Dental Staff, Hospital); Classificação (Classification); Embriologia (Embryology). Já os critérios de inclusão foram: Literatura que aborde a temática em estudo, literatura dos últimos anos, idioma em inglês, estudos laboratoriais e clínicos e revisão sistemática. Revisão de Literatura: As fissuras podem ser definidas por um espaço na união entre dois ossos, geralmente onde haveria uma sutura. As fissuras labiopalatinas fazem parte das anomalias faciais congênitas, decorrentes da não junção dos processos faciais embrionários. Estas alterações ocorrem devido a uma alteração da velocidade migratória das células da crista neural, encarregadas de comandar o fenômeno de fusão das proeminências faciais entre a $6^{a}$ e $9^{a}$ semana de vida embrionária. Conclusão: $O$ tratamento de pacientes com fissuras labiopalatinas requer a abordagem de uma equipe multidisciplinar que envolva médicos desde a área da cirurgia plástica, otorrinolaringologia, pediatria, até geneticistas, dentistas, protéticos, enfermeiros e fonoaudiólogos. Dando assim, enfoque a prevenção, recuperação e reabilitação dos pacientes. Todavia são necessários maiores estudos para uma maior compreensão sobre o tema e as melhores medidas que devem ser aplicadas para cada caso em particular.

Descritores: Fenda Labial; Fissura Palatina; Equipe Hospitalar de Odontologia; Classificação; Embriologia.

\section{Resumen}

Objetivo: El presente estudio tiene como objetivo exponer a través de una revisión de la literatura, la fisura labial y/o palatina (FL/P) y su tratamiento, frente a un enfoque multidisciplinario. Metodología: Esta revisión de la literatura fue realizada por la principal base de datos de salud: Pubmed (https://www.ncbi.nlm.nih.gov/pubmed). Las palabras clave para la búsqueda textual fueron: Labio Leporino; Fisura del Paladar; Personal de Odontología en Hospital; Clasificación; Embriología. Los criterios de inclusión fueron: literatura que aborda el tema en estudio, literatura de los últimos años, idioma inglés, estudios clínicos y de laboratorio y revisión sistemática. Revisión de Literatura: Las fisuras se pueden definir por un espacio en la articulación entre dos huesos, generalmente donde habría una sutura. El labio leporino y el paladar hendido son parte de anomalías faciales congénitas, como resultado de la no unión de los procesos faciales embrionarios. Estos cambios ocurren debido a un cambio en la velocidad migratoria de las células de la cresta neural, a cargo de controlar el fenómeno de fusión de las prominencias faciales entre la $6^{\mathrm{a}}$ y $9^{\mathrm{a}}$ semana de vida embrionaria. Conclusión: El tratamiento de pacientes con fisuras labio-palatinas requiere el enfoque de un equipo multidisciplinario que tenga médicos del campo de la cirugía plástica, otorrinolaringología, pediatría, genetistas, dentistas, prótesis, enfermeras y logopedas. Dando así un enfoque a la prevención, recuperación y rehabilitación de dos pacientes. Todavía hay estudios necesarios para una mejor comprensión del tema y los pasos que se deben tomar para cada caso específico.

Descriptores: Labio Leporino; Fisura del Paladar; Personal de Odontología en Hospital; Clasificación; Embriología.

\section{INTRODUCTION}

The definition of cleft is a space between two bones where they would usually be joined by a suture. The cleft lip and/or palate (CL/CP) are part of the congenital facial anomalies resulting from the non-joining of embryonic facial processes resulting from the lack of fusion of the frontonasal and maxillary processes that occurs around 6th week ${ }^{1}$. The palatine clefts are due to the lack of fusion of the palatine plates of the maxillary process that occurs around the 9 th week ${ }^{2}$.

The classification of (CL/CP) is fundamental, as they may affect distinct areas ${ }^{3}$. The Spina 
classification is currently used, which classified the clefts into four categories, based on the incisive foramen: pre-incisive foramen cleft or cleft lip, postincisive foramen cleft or cleft palate, tran-incisive foramen cleft and cleft lip and palate, and rare facial cleft $^{4}$.

There are numerous etiologies of CL/CP, but the main ones are: heredity, maternal morphological changes, maternal diabetes, hypothyroidism, stress, maternal infections such as toxoplasmosis and rubella, maternal malnutrition, use of certain medications and radiation ${ }^{5}$. Therefore, the most significant factors are genetic and environmental. Thus, it is clear that genetic factors show that the incidence increases according to the presence of cleft family members, where parents who do not have cleft have a $0.1 \%$ chance of having a cleft child. In the condition where there are parents without clefts and a cleft child, approximately $4.5 \%$ chance of having another cleft child. When one parent and first child have cleft, there is a $5 \%$ chance of having another cleft child. Thus, in the presence of hereditary predisposition, the combination of environmental factors may precipitate the appearance of anomaly ${ }^{6}$.

Regarding environmental factors, they can be classified as follows: nutritional, induced by deficiency in the maternal diet during the organogenesis of mineral salts (zinc, copper, iodine, manganese, fluorine) and vitamins (A, riboflavin, folic acid $)^{7}$; chemicals, in cases where there is use of drugs by the pregnant woman (smoking, alcohol and medicines without medical guidance); endocrines, among these substances, cortisone is a wellestablished experimental teratogen, producing cleft lip and palate in almost $100 \%$ of individuals ${ }^{8}$; atomic diseases, the harmful effect of radiation on the fetus is unquestionable and can destroy or modify the ability of cells to multiply and differentiate; and the infectious ones where the mother's contact occurs in the first trimester of pregnancy with diseases (syphilis, rubella, hepatitis C, HIV/AIDS, mycoplasma, epstein barr virus, cytomegalovirus, chronic fatigue syndrome, fibromyalgia, among others) ${ }^{9}$. The present study aims to review the literature about cleft lip and/or palate and their treatments in a multidisciplinary approach.

\section{MATERIAL AND METHOD}

This literature review was conducted by the leading health databases: Pubmed (https://www.ncbi.nlm.nih.gov/pubmed).

The keywords for the textual search were: Cleft Lip; Cleft Palate; Dental Staff; Classification; Embryology. The inclusion criteria were: literature on the subject under study, literature of the last years, english language, laboratory and clinical studies and systematic review. The exclusion criteria were: literature review, letter to the editor, opinion article, duplicate literature in databases and literature on different subjects from the variables under study.

RESULTS

○ Embryology

The CL/CP is formed in intrauterine life, initially the frontal processes are formed, followed by the mandibular, medial, lateral nasal and maxillary ones. During the 4th and 8th week there is a differentiation followed by fusion of the oral cavity forming processes. In this sense, during this period there is a characterization of the human features of the individual ${ }^{10}$.

The palate and face are formed at two different periods, where the primary palate is formed, then the secondary palate. The primary palate gives rise to central structures of the middle face, such as nasal columella, filter, labial tubercle, and premaxilla ${ }^{11}$. The secondary palate originates the palatine processes, which later become the palate itself in the 12th week of intrauterine life. These structures are precursors of the incisive foramen in postnatal life. The union between the secondary palate with the anterior primary palate and the upper part of the nasal septum can create an area of vulnerability and, in the absence of fusion, the fissure is formed ${ }^{12}$.

- Classification of orofacial clefts

The classification of orofacial clefts is necessary as they may manifest in different ways. In Brazil, Spina's classification is the most used, which divides the clefts into four categories, having as reference point the incisive foramen. The characteristics of the main fissures described by Spina, as well as the complementation of information proposed by other authors regarding the original classification are presented in more detail in Chart 1.

The individual will have speech hypernasality, and the symptom that the baby with this type of cleft presents is the leakage of milk through the nose. When submucosal, diagnosis is only possible through a nasofibroscopy.

○ Etiology

The CL/CP are determined by multiple factors, which may be genetics and non-genetics; this is called multifactorial inheritance. Thus, there is no specific factor that can be responsible for orofacial clefts. However, it is interesting to clarify that there are a number of aspects that are responsible for embryonic change in the first two months of pregnancy. Such as mutant genes: deformities associated with other rare syndromes and congenital changes in the limb; chromosomal aberrations: when associated with syndromes such as D-trisomy; teratogenic agents; multifactorial inheritance: most cases fall into this category, however there could be a familial tendency not to obey a mendelian pattern and not present, or at least demonstrable, chromosomal 
aberrations $^{13}$. Other factors recently highlighted in the literature are: maternal morphological changes, maternal diabetes, hypothyroidism, stress, maternal infections such as toxoplasmosis and rubella, maternal malnutrition, hormones, infection agents, drugs, use of certain medications and radiation ${ }^{14}$.

Chart 1. Spina classification and authors' complements, author/year, type of study, definition.

\begin{tabular}{|c|c|c|c|}
\hline $\begin{array}{c}\text { Spina } \\
\text { classification }\end{array}$ & $\begin{array}{c}\text { Author } / \text { ye } \\
\text { ar }\end{array}$ & $\begin{array}{l}\text { Type of } \\
\text { study }\end{array}$ & Definition \\
\hline $\begin{array}{l}\text { Pre-incisive } \\
\text { foramen cleft }\end{array}$ & $\begin{array}{l}\text { Rodrigues } \\
\text { et al., } \\
2018^{17} \text {; } \\
\text { Spina, } \\
1973^{21}\end{array}$ & $\begin{array}{l}\text { Clinical } \\
\text { study } \\
\text { (In vivo) }\end{array}$ & $\begin{array}{l}\text { Exclusively lip fissure due to the lack of fusion of } \\
\text { the maxillary processes with the median nasal } \\
\text { processes. It may be unilateral, bilateral or } \\
\text { median and complete or incomplete. It is } \\
\text { complete when small fissures occur in the } \\
\text { vermilion mucosa and/or lip skin and complete } \\
\text { rupture of the lip and alveolar ridge, passing } \\
\text { through the floor of the nose and ending in the } \\
\text { incisive foramen. This type of cleft when not } \\
\text { involving the alveolar ridge does not present } \\
\text { dental anomalies. The nasal tip is deflected to the } \\
\text { non-fissured side. }\end{array}$ \\
\hline $\begin{array}{l}\text { Post-incisive } \\
\text { foramen cleft }\end{array}$ & $\begin{array}{l}\text { Ortiz- } \\
\text { Posadas et } \\
\text { al., 2001'保; } \\
\text { Spina et } \\
\text { al., } 1972^{19}\end{array}$ & $\begin{array}{l}\text { Clinical } \\
\text { study } \\
\text { (In vivo) }\end{array}$ & $\begin{array}{l}\text { They are the palatal clefts resulting from the lack } \\
\text { of fusion of the palatal processes with each other } \\
\text { and with the nasal septum. They are medium and } \\
\text { can only affect uvula, soft palate (incomplete) or } \\
\text { when there is involvement of the hard palate } \\
\text { (incomplete/complete). In this type of cleft there } \\
\text { is no aesthetic problem as in the others, but it } \\
\text { leads to a nasal resonance of speech due to the } \\
\text { inadequate function of the pharyngeal fleece } \\
\text { mechanism. It is the most common fissure to be } \\
\text { found associated to other birth defects. The } \\
\text { mildest form of this fissure is the bifid uvula, } \\
\text { which does not always require a therapeutic } \\
\text { approach. }\end{array}$ \\
\hline $\begin{array}{l}\text { Tran-incisive } \\
\text { foramen cleft }\end{array}$ & $\begin{array}{l}\text { Spina et } \\
\text { al., } 1972^{19}\end{array}$ & $\begin{array}{l}\text { Clinical } \\
\text { study } \\
\text { (In vivo) }\end{array}$ & $\begin{array}{l}\text { It is due to the non-fusion of the mesenchyme of the } \\
\text { lateral palatal processes of the palate and nasal } \\
\text { septum. Reaches lip, alveolar arch and all palate. It can } \\
\text { be unilateral or bilateral and complete or incomplete } \\
\text { (when the lip is not affected). It is the most severe form } \\
\text { of cleft. }\end{array}$ \\
\hline $\begin{array}{l}\text { Rare facial } \\
\text { cleft }\end{array}$ & $\begin{array}{l}\text { Allori et } \\
\text { al., } \\
2017^{20} \text {; } \\
\text { Spina } \\
1973^{21}\end{array}$ & $\begin{array}{l}\text { Clinical } \\
\text { study } \\
\text { (In vivo) }\end{array}$ & $\begin{array}{l}\text { They involve lips, nose, eyes and jaw. There are also } \\
\text { cases with muscle tissue (soft palate) or bone (hard } \\
\text { palate) deficiency under the intact mucous layer, giving } \\
\text { a false idea of normality. The most evident sign is } \\
\text { located in the midline of the palate, which will have a } \\
\text { much lighter coloration than the rest of the mucosa. It } \\
\text { is often associated with the presence of a bifid uvula. }\end{array}$ \\
\hline
\end{tabular}

The $(\mathrm{CL} / \mathrm{CP})$ fall into two distinct groups, from the etiological point of view: cleft lip (unilateral or bilateral), resulting from the lack of fusion of nasal processes of frontal prominence with the maxillary process between 5th and 7th week of embryonic development, and the cleft palate, resulting from the lack of fusion of the bilateral processes at midline independent of the maxilla around the 10th week of intrauterine life.

\section{○ Diagnosis}

The diagnosis can be made prenatally by ultrasound exams, specifically the nuchal translucency ultrasound, and the visualization of the nose and lips can be made around the 12th week of gestation, thus identifying the cleft lip and cleft palate $^{14}$.

The diagnosis of prenatal cleft lip and palate depends on the topography of the face in multiple planes, experience in the technique and observation on the degree of tongue curl. In this stage it is important to reassure parents, giving access to all information related to cleft so that they are prepared for the sequential steps, before and after childbirth, with confirmation of the diagnosis ${ }^{15}$.

The professionals involved in the diagnosis and treatment of this child should be prepared to communicate the family and this intervention must be understandable, without the use of technical terms, in a privacy place, in which they cannot be interrupted, so that the family can feel supported and oriented regarding the necessary care for this child.

\section{- Treatment}

It is indispensable that patients with this condition have to be evaluated and followed up at referral centers by a multidisciplinary team, mainly composed of dental surgeons, plastic surgeons, geneticists, otolaryngologists and speech pathologists ${ }^{17}$.

Thus, from birth to adulthood, full professional support will be available, assisting in the treatment of cleft patients in order to provide satisfactory aesthetic and functional results (phonation and dental occlusion), allowing these patients better inclusion in society ${ }^{18}$.

\section{- Special Cares}

The baby with craniofacial anomaly may require some care in the feeding moment. The conduct during feeding this baby depends on five points (Chart 2).

Chart 2. Special cares at the time of feeding for the baby with craniofacial anomaly

\begin{tabular}{|l|l|}
\hline \multicolumn{1}{|c|}{ Care } & \multicolumn{1}{|c|}{ Author/Year } \\
\hline $\begin{array}{l}\text { Assessment of the suction pattern by the } \\
\text { speech pathologists in order to verify the } \\
\text { indication of the case: oral feeding, use of } \\
\text { nasal tube and/or other alternative (such } \\
\text { as gastrostomy, always seeking the } \\
\text { development of the baby }\end{array}$ & $\begin{array}{l}\text { Spina et al. }{ }^{19} \\
1972\end{array}$ \\
\hline $\begin{array}{l}\text { Clinical evaluation by the pediatrician in } \\
\text { order to define nutritional issues of the } \\
\text { baby }\end{array}$ & $\begin{array}{l}\text { Allori et al. }{ }^{20} \\
2017\end{array}$ \\
\hline $\begin{array}{l}\text { Evaluation with the plastic surgeon in } \\
\text { order to verify anatomo-functional issues }\end{array}$ & $\begin{array}{l}\text { Spina }{ }^{21} \\
1973\end{array}$ \\
\hline $\begin{array}{l}\text { Clinical investigation by the geneticist to } \\
\text { verify the presence of other alterations }\end{array}$ & $\begin{array}{l}\text { Yun-Chia et al. }{ }^{22} \\
2018\end{array}$ \\
\hline $\begin{array}{l}\text { Evaluation of emotional aspects with the } \\
\text { psychologist in order to verify affective } \\
\text { conditions of the family in the care of the } \\
\text { baby }\end{array}$ & $\begin{array}{l}\text { Garib et al. }{ }^{23} \\
2018\end{array}$ \\
\hline
\end{tabular}

\section{DISCUSSION}

Although numerous articles have been published in recent years, there is a lack of information that provides sufficient support for the treatment of orofacial cleft in a multidisciplinary approach. The cleft lip and cleft palate are the most common defect affecting the face and its treatment consists in the surgical reconstruction of the anatomical structures of the cleft. Part of the surgical treatment is the reconstruction of the alveolar bone by autogenous bone graft (osteoplasty). The orofacial clefts correspond to the process of congenital malformation during the embryonic period in which there is no junction between two bones through a suture. The causes of these anomalies are not yet known. However, it is known that the race, sex and age of the parents predispose this disease ${ }^{10}$.

The type of cleft will directly influence the neonatal life of the individual affected by these pathologies, thus, cleft lip and palate (tran-foramen) 
or just palate (post-foramen) clefts make breastfeeding difficult, since the baby has difficulty extracting milk, and may feel fatigue and consequently ingesting insufficient milk. In cases of pre-foramen (lips) clefts is possible to maintain exclusively breastfeeding ${ }^{24}$. In cases of clefts in which the palate is compromised, the baby usually has the preserved sucking reflex, but due to the "decrease in intraoral pressure" due to the presence of the cleft, it is difficult to stay with breastfeeding exclusively, since this can lead to poor nutrition for the baby's development ${ }^{25}$. In cases of cleft palate, the mother is instructed to feed breast milk by bottle. The first indicated milk is always the mother's milk, and on the advice of a pediatrician, the mother can complete breastfeeding with artificial milk ${ }^{26}$. It is essential that the crack region is cleaned after feeding using a cotton swab or the tip of a diaper moistened with boiled or filtered water. This will remove excess milk that may be deposited on the alveolar rims (gums), nostrils and tongue. Commonly, the baby's lip dries out and forms cracks and if this occurs it is recommended to use mineral oil to hydrate ${ }^{27}$.

Fissures can still be diagnosed during intrauterine life with ultrasound examinations. The non-syndromic condition of the lip and/or palate is considered a multifactorial condition, in which cleft is an isolated phenotype and distinct from syndromic forms. There is a coding variant in the MSX1 gene that is predicted to be harmful ${ }^{7}$. However, in cases where there are no associated syndromes or complications due to cleft palate, these conditions may be associated with the presence of dental anomalies, including congenitally missing permanent teeth, supernumerary teeth, microdontic, and macrodontic teeth in the anterior maxillary region, presence of malformed permanent cleft-sided lateral incisor, positions of the permanent lateral incisors relative to the cleft side and presence of rotated cleftsided central incisors ${ }^{16}$. The prevalence and distribution of hypodontia in patients with cleft lip and palate is higher than in healthy patients, which is an important aspect to consider for functional and aesthetic oral rehabilitation ${ }^{24}$. In this context, professional follow-up should act from intrauterine life, with the awareness of parents, until the adult life of the individual, allowing him to have quality of life as an adult through aesthetic and functional results in the treatment of fissures ${ }^{18}$.

The prognosis is considered good when there are no associated malformations or complications due to orofacial clefts. Unfortunately prevention is not yet a reality as it is a multifactorial disease. However, with advances in medicine, diagnosis and treatment are performed early, and treatments are more favorable when performed in the individual's childhood $^{28}$. For some authors, it is necessary to develop a multidisciplinary care strategy, since the satisfaction of the final aesthetic result is reduced when the individual is treated with individual care1,4. When the adopted approach involves orthognathic surgeries, future surgeries are not ruled out and appear in $86.9 \%$ of cases ${ }^{22}$. Early surgical bone anchorage for these patients is a promising orthopedic procedure in the treatment of patients with unilateral complete cleft lip and palate, with the advantage of achieving early improvement in facial aesthetics and functional occlusion ${ }^{23}$.

In general, surgical treatments are complex but necessary. In the vast majority of cases the asymmetry of the median facial structures is a major concern for patients with unilateral cleft lip and palate and the main objective of treatment is to restore symmetry. Even in the presence of protruding premaxilla, these patients may obtain adequate lip and nasal results after undergoing primary lip repair and nasal reconstruction ${ }^{25}$. Although it can be diagnosed in intrauterine life, the causes of orofacial clefts are not yet known. However, it is known that parents' race, sex and age are predisposing factors. Considering the need of several interventions, surgical or not, and the participation of various professionals in the treatment of individuals with these anomalies, a multidisciplinary approach is very important for a satisfactory result ${ }^{29-31}$.

\section{FINAL CONSIDERATIONS}

It can be concluded from this study that the treatment of patients with orofacial clefts requires the approach of a multidisciplinary team that involves physicians in the area of plastic surgery, otorhinolaryngology, pediatrics, geneticists, dentists, prosthetics, nurses and speech pathologists, focusing on patient prevention, recovery and rehabilitation. However, further studies are needed for a better understanding of the subject and the steps that should be applied for each particular case.

\section{REFERENCES}

1. Shaw WC, Brattström V, Mølsted K, PrahlAndersen B, Roberts CT, Semb G. The Eurocleft study: intercenter study of treatment outcome in patients with complete cleft lip and palate. Part 5: discussion and conclusions. Cleft Palate Craniofac J. 2005;42(1):93-8.

2. Friede H, Lilja J. The Eurocleft Study: Intercenter study of treatment outcome in patients with complete cleft lip and palate. Cleft Palate Craniofac J. 2005;42(4):453-54.

3. Rosenstein SW, Grasseschi M, Dado D. The Eurocleft Study: Intercenter study of treatment outcome in patients with complete cleft lip and palate. Cleft Palate Craniofac J. 2005;42(4):453.

4. Semb G, Brattström V, Mølsted K, PrahlAndersen B, Zuurbier P, Rumsey N, Shaw WC. The Eurocleft study: intercenter study of treatment outcome in patients with complete cleft lip and 
palate. Part 4: relationship among treatment outcome, patient/parent satisfaction, and the burden of care. Cleft Palate Craniofac J. 2005;42(1):83-92.

5. Watkins SE, Meyer RE, Strauss RP, Aylsworth AS. Classification, epidemiology, and genetics of orofacial clefts. Clin Plast Surg. 2014;41(2):149-63.

6. Coleman JR Jr, Sykes JM. The embryology, classification, epidemiology, and genetics of facial clefting. Facial Plast Surg Clin North Am. 2001;9(1):1-13.

7. Pengelly RJ, Arias L, Martínez J, Upstill-Goddard R, Seaby EG, Gibson J, Ennis S, Collins A, Briceño I. Deleterious coding variants in multicase families with non-syndromic cleft lip and/or palate phenotypes. Sci Rep. 2016;6:30457.

8. Ren Y, Steegman R, Dieters A, Jansma J, Stamatakis H. Bone-anchored maxillary protraction in patients with unilateral complete cleft lip and palate and Class III malocclusion. Clin Oral Investig. 2019;23(5):2429-2441.

9. Alberconi TF, Siqueira GLC, Sathler R, Kelly KA, Garib DG. Assessment of Orthodontic Burden of Care in Patients With Unilateral Complete Cleft Lip and Palate. Cleft Palate Craniofac J. 2018;55(1):74-78.

10. Eriguchi M, Watanabe A, Suga K, Nakano Y, Sakamoto T, Sueishi K, Uchiyama T. Growth of Palate in Unilateral Cleft Lip and Palate Patients Undergoing Two-stage Palatoplasty and Orthodontic Treatment. Bull Tokyo Dent Coll. 2018;59(3):183-91.

11. Smane L, Pilmane M. Evaluation of the presence of MMP-2, TIMP-2, BMP2/4, and TGF $\beta 3$ in the facial tissue of children with cleft lip and palate. Acta Med Litu. 2018;25(2):86-94.

12. AlHayyan WA, Pani SC, AlJohar AJ, AlQatami FM. The Effects of Presurgical Nasoalveolar Molding on the Midface Symmetry of Children with Unilateral Cleft Lip and Palate: A Long-term Follow-up Study. Plast Reconstr Surg Glob Open. 2018;6(7):e1764.

13. Thakur S, Singh A, Thakur NS, Diwana VK. Achievement in Nasal Symmetry after Cheiloplasty in Unilateral Cleft Lip and Palate Infants Treated with Presurgical Nasoalveolar Molding. Contemp Clin Dent. 2018;9(3):357-60.

14. Turri de Castro Ribeiro T, Petri Feitosa MC, Almeida Penhavel R, Zanda RS, Janson G, Mazzottini R, Garib DG. Extreme maxillomandibular discrepancy in unilateral cleft lip and palate: Longitudinal follow-up in a patient with mandibular prognathism. Am J Orthod Dentofacial Orthop. 2018;154(2):294-304.

15. Perillo L, Vitale M, d'Apuzzo F, Isola G, Nucera $\mathrm{R}$, Matarese G. Interdisciplinary approach for a patient with unilateral cleft lip and palate. Am J Orthod Dentofacial Orthop. 2018;153(6):883-94.
16. Hoffmannova E, Moslerová V, Dupej J, Borský J, Bejdová Š, Velemínská J. Three-dimensional development of the upper dental arch in unilateral cleft lip and palate patients after early neonatal cheiloplasty. Int $\mathrm{J}$ Pediatr Otorhinolaryngol. 2018;109:1-6.

17. Tan ELY, Kuek MC, Wong HC, Ong SAK, Yow M. Secondary Dentition Characteristics in Children With Nonsyndromic Unilateral Cleft Lip and Palate: A Retrospective Study. Cleft Palate Craniofac J. 2018;55(4):582-89.

18. Rodrigues $\mathrm{R}$, Fernandes $\mathrm{MH}$, Monteiro $\mathrm{AB}$, Furfuro R, Sequeira T, Silva CC, Manso MC. SPINA classification of cleft lip and palate: A suggestion for a complement. Arch Pediatr. 2018;25(7):439-41.

19. Ortiz-Posadas MR, Vega-Alvarado L, MayaBehar J. A new approach to classify cleft lip and palate. Cleft Palate Craniofac J. 2001;38(6):545-50.

20. Spina V, Psillakis JM, Lapa FS, Ferreira MC. Classificação das fissuras lábio-palatinas. Sugestão de modificação [Classification of cleft lip and cleft palate. Suggested changes]. Rev Hosp Clin Fac Med Sao Paulo. 1972;27(1):5-6.

21. Allori AC, Mulliken JB, Meara JG, Shusterman S, Marcus JR. Classification of Cleft Lip/Palate: Then and Now. Cleft Palate Craniofac J. 2017;54(2):175-88.

22. Spina V. A proposed modification for the classification of cleft lip and cleft palate. Cleft Palate J. 1973;10:251-2.

23. Yun-Chia Ku M, Lo LJ, Chen MC, Wen-Ching Ko E. Predicting need for orthognathic surgery in early permanent dentition patients with unilateral cleft lip and palate using receiver operating characteristic analysis. Am J Orthod Dentofacial Orthop. 2018;153(3):405-14.

24. Garib D, Yatabe M, de Souza Faco RA, Gregório L, Cevidanes L, de Clerck H. Bone-anchored maxillary protraction in a patient with complete cleft lip and palate: A case report. Am J Orthod Dentofacial Orthop. 2018;153(2):290-97.

25. De Stefani A, Bruno G, Balasso P, Mazzoleni S, Baciliero U, Gracco A. Teeth agenesis evaluation in an Italian sample of complete unilateral and bilateral cleft lip and palate patients. Minerva Stomatol. 2018;67(4):156-64.

26. Chang SY, Lonic D, Pai BC, Lo LJ. Primary Repair in Patients With Unilateral Complete Cleft of Lip and Primary Palate: Assessment of Outcomes. Ann Plast Surg. 2018;80(2S Suppl 1):S2-6.

27. Vura N, Gaddipati R, Palla Y, Kumar P. An Intraoral Appliance to Retract the Protrusive Premaxilla in Bilateral Cleft Lip Patients Presenting Late for Primary Lip Repair. Cleft Palate Craniofac J. 2018;55(4):622-25.

28. Massie JP, Bruckman K, Rifkin WJ, Runyan CM, Shetye PR, Grayson B, Flores RL. The Effect of 
Nasoalveolar Molding on Nasal Airway Anatomy: A 9-Year Follow-up of Patients With Unilateral Cleft Lip and Palate. Cleft Palate Craniofac J. 2018;55(4):596-601.

29. Jabbari F, Wiklander L, Reiser E, Thor A, Hakelius M, Nowinski D. Secondary Alveolar Bone Grafting in Patients Born With Unilateral Cleft Lip and Palate: A 20-Year Follow-up. Cleft Palate Craniofac J. 2018;55(2):173-79.

30. Jones CM, Roth B, Mercado AM, Russell KA, Daskalogiannakis J, Samson TD, Hathaway RR, Smith A, Mackay DR, Long RE Jr. The Americleft Project: Comparison of Ratings Using Two-Dimensional Versus Three-Dimensional Images for Evaluation of Nasolabial Appearance in Patients With Unilateral Cleft Lip and Palate. J Craniofac Surg. 2018;29(1):105-8.

31. Gatti GL, Freda N, Giacomina A, Montemagni M, Sisti A. Cleft Lip and Palate Repair. J Craniofac Surg. 2017;28(8):1918-24.

\section{CONFLICTS OF INTERESTS}

The authors declare no conflicts of interests.

\section{CORRESPONDING AUTHOR}

\section{Jefferson David Melo de Matos}

Department of Dental Materials and Prosthodontics, São Paulo State University (Unesp), Institute of Science and Technology, São José dos Campos - SP.

Avenida Engenheiro Francisco José Longo, 777/778, Jardim São Dimas,

12245-000 São José dos Campos - SP, Brasil

Phone: +55 (88) 99603-9595.

e-mail: matosjefferson19@gmail.com
Received 19/09/2019

Accepted 21/04/2020 